\title{
Karakteristik Mutu Jamur Tiram (Pleurotus ostreatus) Menggunakan Berbagai Metode Pengemasan pada Penyimpanan Suhu Rendah
}

\section{Quality Characteristics of Oyster Mushrooms (Pleurotus ostreatus) Using Various Packaging Methods in Low Temperature Storage}

\author{
Ayu Aulia Aftukha ${ }^{1 凶}$, Dian Purbasari ${ }^{1}$ \\ ${ }^{1}$ Departemen Teknik Pertanian, Fakultas Teknologi Pertanian, Universitas Jember \\ ${ }^{\square}$ Komunikasi Penulis, email: ayua66375@gmail.com \\ DOI:http://dx.doi.org/10.23960/jtep-l.v10i3.327-337 \\ Naskah ini diterima pada 17 Juli 2021; revisi pada 8 Agustus 2021; \\ disetujui untuk dipublikasikan pada 22 Agustus 2021
}

\begin{abstract}
Oyster mushrooms (Pleurotus ostreatus) include holticulture products that have a high moisture content. High water content can speed up the process of respiration rate, causing oyster mushrooms to easily damage. An alternative that can be used to overcome the problem of oyster mushroom damage is to slow down the rate of respiration by packaging. The purpose of this study is to analyze the quality characteristics of oyster mushrooms as well as the influence of packaging methods and storage time at low temperatures $\left(5^{\circ} \mathrm{C}\right)$. This study used two factors, namely packaging method and storage length. The data was analyzed using factorial anova two mix factors with tests ( $a=5 \%)$, if obtained differently real then conducted follow-up test Tukey. The results showed the best packaging method is found in vacuum packaging with the highest texture value of 0,004 N/mm2. The highest color brightness value is 83,15 . The lowest moisture content value is $88 \%$. The lowest water activity value was 0,895 and the lowest weight was $2,47 \%$.
\end{abstract}

Keywords : oyster mushrooms, packaging, storage, temperature, quality

\begin{abstract}
ABSTRAK
Jamur tiram (Pleurotus ostreatus) termasuk produk hortikultura yang memiliki kadar air yang tinggi. Kadar air yang tinggi dapat mempercepat proses laju respirasi, sehingga menyebabkan jamur tiram mudah mengalami kerusakan. Alternatif yang dapat digunakan untuk mengatasi masalah kerusakan jamur tiram yaitu memperlambat laju respirasi dengan cara dilakukan pengemasan. Tujuan dari penelitian ini yaitu menganalisis karakteristik mutu jamur tiram serta pengaruh metode pengemasan dan lama penyimpanan pada suhu rendah (5 !). Penelitian ini menggunakan RAL (Rancangan acak lengkap) dua faktor yaitu metode pengemasan dan lama penyimpanan. Data dianalisis menggunakan faktorial anova two mix factors dengan tes $(\mathrm{a}=5 \%)$, jika diperoleh berbeda nyata kemudian dilakukan uji lanjutan Tukey. Hasil penelitian menunjukkan metode pengemasan terbaik terdapat pada pengemasan vakum dengan nilai tekstur (hardness) tertinggi sebesar 0,004 N/mm2. Nilai derajat putih tertinggi sebesar 83,15. Nilai kadar air terendah sebesar $88 \%$. Nilai aktivitas air terendah sebesar 0,895 dan susut bobot terendah sebesar $2,47 \%$.
\end{abstract}

Kata Kunci: jamur tiram, pengemasan, penyimpanan, suhu, mutu

\section{PENDAHULUAN}

Jamur tiram (Pleurotus ostreatus) merupakan salah satu jenis jamur kayu yang banyak dikenal dan dikonsumsi dikalangan masyarakat karena kandungan gizi yang tinggi dibandingkan jamur lainnya. Jamur tiram memiliki kadar air yang tinggi (73,7-90,8\%). Menurut Maula et al., (2018) , setiap 100 g jamur tiram mengandung protein sebesar 5,94\%, karbohidrat sebesar $50,59 \%$, serat sebesar $1,56 \%$, lemak sebesar $0,17 \%$ selain itu jamur juga mengandung zat besi, tembaga, kalium serta vitamin B dan D.

Menurut Badan Pusat Statistik (2019), volume impor jamur tiram masih lebih tinggi dibandingkan volume ekspor jamur tiram. Volume impor sebesar $33.163 .188 \mathrm{~kg}$ sedangkan 
volume ekspor sebesar $18.392 .000 \mathrm{~kg}$. Indonesia memiliki potensi yang besar untuk memenuhi pasar dalam negeri maupun ekspor jamur dalam bentuk segar. Kendala yang dihadapi adalah jamur tiram segar tidak dapat bertahan lama dalam suhu ruang sehingga perlu penanganan untuk memperpanjang kesegarannya. Sesuai dengan pendapat Cahya et al., (2014), waktu simpan jamur tiram putih pada suhu ruang tanpa kemasan hanya dapat bertahan 1 hari, sedangkan perjalanan yang diperlukan untuk sampai ke konsumen rata-rata lebih dari itu, sehingga perlu adanya penanganan khusus agar jamur dapat bertahan selama mungkin hingga sampai pada konsumen masih dalam kondisi segar dan layak dikonsumsi.

Usaha yang dapat digunakan untuk mengatasi masalah penanganan pascapanen adalah melakukan pengemasan menggunakan kemasan plastik dan disimpan pada suhu rendah $\left(5^{\circ} \mathrm{C}\right)$. Proses penyimpanan berperan penting terhadap kualitas bahan pangan. Saat masa penyimpanan, bahan pangan sangat dipengaruhi oleh suhu dan kelembaban udara sekitar (Marbun et al., 2019). Pengukuran karakteristik mutu dilakukan untuk mengetahui mutu jamur tiram selama proses penyimpanan berlangsung pada suhu rendah ( 5 ). Penelitian tentang pengemasan jamur tiram dalam kemasan plastik pernah dilakukan Arianto et al., (2006), salah satu alternatif dalam mengatasi laju respirasi pascapanen bahan pangan dengan penyimpanan dingin dapat juga menggunakan lubang dengan cara melubangi kemasan plastik dengan 4 lubang. Selain itu terdapat penelitian Zulfika (2018), dalam jurnal peningkatan daya tahan jamur tiram pengemasan jamur tiram dengan metode vakum memiliki keuntungan yaitu jamur dapat bertahan lebih lama dan salah satunya dapat menyimpan persediaan jamur dengan lebih banyak. Pada penelitian kali ini metode pengemasan yang digunakan yaitu pengemasan tidak berlubang, berlubang dan vakum kemudian disimpan pada suhu rendah (5) dengan lama penyimpanan yang berbeda yaitu hari ke 0,2 dan 4 . Untuk mengetahui mutu jamur tiram maka perlu dilakukan penelitian karakteristik mutu jamur tiram yang dihasilkan meliputi tekstur (hardness), derajat putih , kadar air, susut bobot dan aktivitas air $\left(\mathrm{a}_{\mathrm{w}}\right)$.

\section{BAHAN DAN METODE}

Penelitian ini dilaksanakan pada bulan Januari 2021 sampai Februari 2021 di Laboratorium Enjiniring Hasil Pertanian, Jurusan Teknik Pertanian, Fakultas Teknologi Pertanian, Universitas Jember. Alat yang digunakan pada penelitian ini adalah timbangan digital, Colorimeter CS-10, Vacuum sealer kris vs200; kamera HP, plastik polyethilen $0,80 \mathrm{~mm}$, desikator, cawan, penjepit kayu, penetrometer, showcase, LabSwift Water Activity. dan oven, sedangkan bahan yang digunakan pada penelitian adalah jamur tiram segar baru dipanen.

\subsection{Tahapan Penelitian}

Pengolahan data menggunakan Ms. Excel dengan analisis faktorial anova two mix fators, dan uji lanjutan Tukey. Penelitian ini dilakukan dengan tiga tahap metode percobaan, yaitu sebagai berikut:

\section{Tahap Persiapan}

Tahap persiapan yang dilakukan sebelum melakukan penelitian meliputi:

a) Menyiapakan peralatan yang digunakan dalam penelitian yang akan dilakukan

b) Memilih jamur tiram dalam kondisi baik yaitu : memiliki warna putih bersih dan tudung yang utuh/tidak robek.

2.Tahap Pengemasan

Penyimpanan jamur tiram segar pada suhu rendah $\left(5^{\circ} \mathrm{C}\right)$ dengan metode pengemasan $(\mathrm{P})$ dan lama penyimpanan ( $\mathrm{T}$ ) yang berbeda. Jumlah bahan baku yang digunakan setiap perlakuan sebanyak 100 gram. Perlakuan tersebut antara lain adalah :

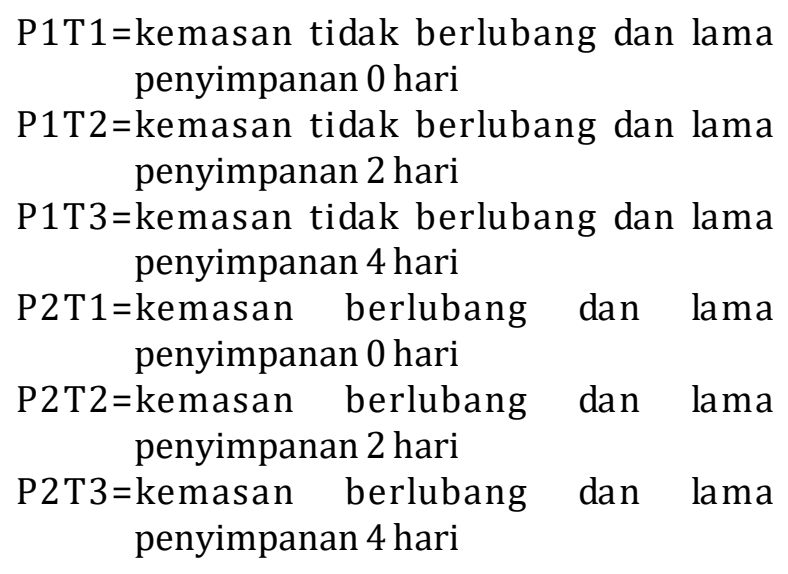


P3T1= kemasan vakum dan lama penyimpanan 0 hari

P3T2= kemasan vakum dan lama penyimpanan 2 hari

P3T3= kemasan vakum dan lama penyimpanan 4 hari

3. Tahap Pengamatan

Pengamatan dalam penelitian ini meliputi:

a) Tekstur (hardness)

Tekstur dapat dihitung dengan menggunakan persamaan:

$$
\text { Pnt }=\frac{(g * M K)}{R P^{2} *\left(\tan ^{2} a\right)}
$$

dimana, Pnt adalah penetrasi $\left(\mathrm{N} / \mathrm{mm}^{2}\right)$, g adalah gravitasi $\left(\mathrm{m} / \mathrm{s}^{2}\right)$, MK adalah massa kerucut $(\mathrm{kg})$, dan $\mathrm{RP}$ adalah rata-rata pengukuran (mm/kg.s).

b) Derajat putih

Pengukuran derajat putih dilakukan dengan menggunakan alat colorimeter. Pada alat tersebut, nilai derajat putih akan terbaca secara kuantitatif sebagai nilai L. Dimana nilai L memiliki rentang nilai 0-100. Semakin cerah jamur tiram, maka nilainya mendekati 100.

c) Kadar Air

Kadar air bahan dapat dihitung dengan menggunakan persamaan:

$$
\mathrm{Mo}=\frac{(W o-W n)}{W o} * 100 \%
$$

dimana, Mo adalah persen kadar air, Wo adalah berat sampel awal sebelum di oven ( $\mathrm{g}$ ), dan $\mathrm{Wn}$ adalah berat sampel setelah di oven (g). d) Aktivitas Air

Pengukuran aktivitas air dilakukan dengan menggunakan alat LabSwift Water Activity.

e) Susut Bobot

Susut bobot bahan dapat dihitung dengan menggunakan persamaan:

$$
\% \text { kehilangan berat }=\frac{W 0-W 1}{w_{0}} * 100 \%
$$

dimana, W0 adalah berat awal bahan (g) dan $\mathrm{W} 1$ adalah berat saat pengamatan $(\mathrm{g})$.

\section{HASIL DAN PEMBAHASAN}

\subsection{Tekstur (Hardness) Jamur Tiram}

Tekstur (hardness) merupakan gaya yang diberikan pada objek hingga terjadi perubahan bentuk (deformasi). Semakin tinggi nilai tekstur (hardness) berarti semakin besar gaya (g) yang dibutuhkan untuk menekan produk, sehingga semakin keras produk tersebut (Ann et al., 2012). Grafik perubahan tekstur (hardness) pada berbagai metode pengemas dan lama penyimpanan dapat dilihat pada Gambar 1 .

Gambar 1 menunjukkan bahwa nilai tekstur (hardness) jamur tiram mengalami penurunan seiring dengan lamanya proses penyimpanan. Nilai tekstur (hardness) tertinggi pada hari keempat terdapat pada jamur yang dikemas secara vakum yaitu sebesar $0,004 \mathrm{~N} / \mathrm{mm}^{2}$. Sedangkan nilai tekstur terendah ada pada penyimpanan hari keempat dengan jamur yang dikemas secara tidak berlubang yaitu sebesar $0,002 \mathrm{~N} / \mathrm{mm}^{2}$. Pada pengemasan vakum diperoleh hasil yang lebih baik dikarenakana kondisi pengemasan vakum dapat menghambat sirkulasi udara yang dibutuhkan untuk proses

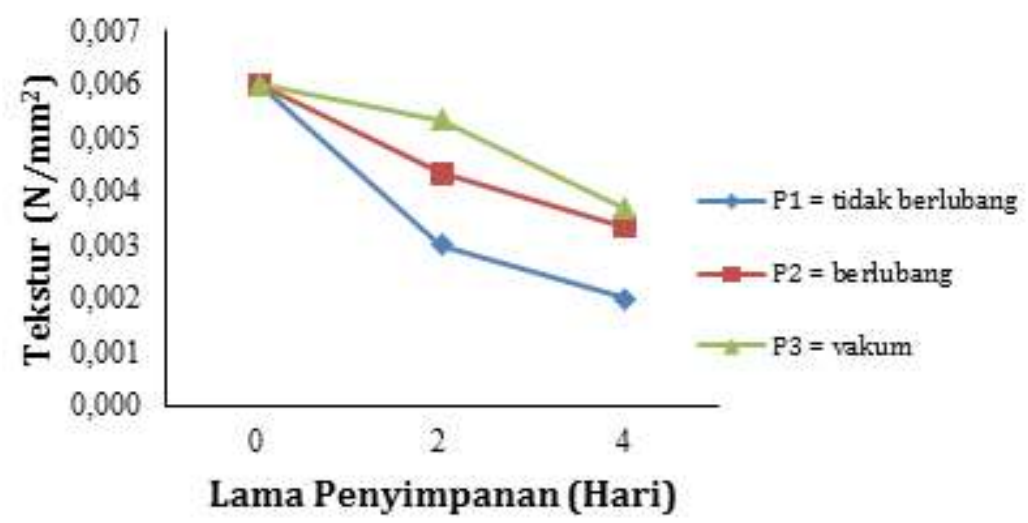

Gambar 1. Grafik Perubahan Tekstur (Hardness) Jamur Tiram 
respirasi sehingga mencegah bertambahnya uap air. Hal ini dapat meminimalisir aktivitas mikroorganisme penyebab pelunakan tekstur (hardness) jamur tiram. Faktor biotik penyebab kerusakan pascapanen meliputi serangan mikroorganisme baik jamur, bakteri atau khamir. Jamur khamir dapat menyerang jamur tiram saat kondisi aktivitas air dan kadar air jamur tiram tinggi. Pengemasan berlubang memiliki nilai tekstur terendah dihari keempat, tekstur (hardness) pada pengemasan berlubang lebih lunak dibandingkan pengemasan tidak berlubang, Hal ini dapat terjadi karena terjadi respirasi yang lebih tinggi pada pengemasan berlubang dibandingkan pengemasan tidak berlubang, sesuai pada pengamatan jamur yang dikemas dengan cara berlubang memiliki butir air lebih banyak di dalam dinding kemasan, dibandingkan dengan pengemasan tidak berlubang. Meningkatnya kadar air tersebut seiring dengan meningkatnya aktivitas air, menurut Arizka dan Daryatmo (2015), Aktivitas air yang meningkat dapat disebabkan oleh aktivitas mikroorganisme yang mendegradasi protein menjadi senyawa yang lebih sederhana dan menyebabkan kemampuan protein mengikat air menurun. Penurunan daya ikat air dari protein tersebut menyebabkan tekstur (hardness) menjadi lunak. Selain itu, aktivitas mikroba meningkat, karena nilai $a_{w}$ meningkat dan peningkatan nilai dikarenakan kegiatan metabolisme jamur dan ditandai dengan tingginya proses respirasi pada jamur, karena jamur termasuk produk yang laju respirasinya tinggi. Berikut tabel perhitungan Anova dua arah dan Tukey dari metode pengemasan (Tabel 2) dan lama penyimpanan (Tabel 3).

Hasil uji Anova diperoleh hasil berbeda nyata antara metode pengemasan dan lama penyimpanan terhadap nilai tekstur jamur tiram. Hasil uji Tukey menunjukkan bahwa masingmasing metode pengemasan berbeda nyata. Tetapi tidak dengan metode pengemasan tidak berlubang dengan berlubang. Pada lama penyimpanan masing-masing berbeda nyata, kecuali pada lama penyimpanan hari ke 2 dengan 4 tidak terdapat hasil berbeda nyata.

\subsection{Derajat Putih Jamur Tiram}

Warna merupakan salah satu sifat fisik yang digunakan untuk menilai mutu suatu produk. Gambar 2 memperlihatkan perkembangan warna jamur pada berbagai jenis kemasan. Pada

Tabel 1. Uji Anova Dua Arah Metode Pengemasan dan Lama Penyimpanan

\begin{tabular}{ccccccc}
\hline $\begin{array}{c}\text { Variabel } \\
\text { Pengamatan }\end{array}$ & $\begin{array}{c}\text { Sumber } \\
\text { Variasi }\end{array}$ & $\begin{array}{c}\text { Derajat } \\
\text { Bebas }\end{array}$ & $\begin{array}{c}\text { Jumlah } \\
\text { Kuadrat }\end{array}$ & $\begin{array}{c}\text { Kuadrat } \\
\text { Tengah }\end{array}$ & $\begin{array}{c}\text { F } \\
\text { Hitung }\end{array}$ & $\begin{array}{c}\text { F } \\
\text { Tabel }\end{array}$ \\
\hline \multirow{4}{*}{ Tekstur } & Pengemasan & 2 & $1,7 \mathrm{E}-05$ & $8,4 \mathrm{E}-06$ & $15,20^{*}$ & 3,55 \\
& Penyimpanan & 2 & $6,0 \mathrm{E}-05$ & $3,0 \mathrm{E}-05$ & $53,60^{*}$ & 3,55 \\
& Interaksi & 4 & $6,2 \mathrm{E}-06$ & $1,6 \mathrm{E}-06$ & 2,80 & 2,93 \\
& Galat & 18 & $1,0 \mathrm{E}-05$ & $5,6 \mathrm{E}-07$ & & \\
\hline
\end{tabular}

Tabel 2. Uji Tukey Berdasarkan Metode Penyimpanan

\begin{tabular}{clcc}
\hline $\begin{array}{c}\text { Variabel } \\
\text { Pengamatan }\end{array}$ & \multicolumn{1}{c}{ Komparasi } & $\begin{array}{c}\text { Beda } \\
\text { Absolut }\end{array}$ & $\begin{array}{c}\text { Nilai Kritis } \\
\text { (HSD) }\end{array}$ \\
\hline & $\begin{array}{l}\text { Tidak berlubang (P1) dengan } \\
\text { Berlubang (P2) }\end{array}$ & 0,0001 & 0,0008 \\
Tekstur & $\begin{array}{l}\text { Tidak berlubang (P1) dengan } \\
\text { vakum(P3) } \\
\end{array}$ & $0,0015^{*}$ & 0,0008 \\
& Berlubang (P2) dengan vakum(P3) & $0,0016^{*}$ & 0,0008 \\
\hline
\end{tabular}

Tabel 3. Uji Tukey Berdasarkan Lama Penyimpanan

\begin{tabular}{cccc}
\hline Variabel Pengamatan & Komparasi & Beda Absolut & Nilai Kritis (HSD) \\
\hline \multirow{2}{*}{ Tekstur } & 0 dengan 2 & $0,0024^{*}$ & 0,0013 \\
& 0 dengan 4 & $0,0036^{*}$ & 0,0013 \\
& 2 dengan 4 & $0,0011^{*}$ & 0,0013 \\
\hline
\end{tabular}


pengemasan vakum warna jamur pada hari ke4 penyimpanan mengalami perubahan yang sangat kentara.

Perubahan warna dapat terjadi apabila terjadi proses pengemasan serta perlakuan penyimpanan yang dilakukan pada bahan pangan. Hasil pengukuran warna pada jamur tiram dinyatakan dengan nilai $\mathrm{L}$, nilai tersebut merupakan hasil pembacaan alat yang menandakan derajat putih pada jamur tiram. Grafik perubahan derajat putih pada berbagai metode pengemas dan lama penyimpanan dapat dilihat pada Gambar 3.

Berdasarkan Gambar 3 jamur tiram yang dikemas dengan metode tidak berlubang memiliki nilai derajat putih yang cenderung lebih rendah dibandingkan dengan jamur yang dikemas secara berlubang dan vakum. Jamur yang disimpan pada awal penyimpanan kecerahan jamur tiram ada pada kisaran nilai rata-rata 80 - 85. Setelah disimpan selama 2 hari mengalami penurunan sampai 80,36 . Nilai derajat putih tertinggi pada penyimpanan hari keempat dengan metode pengemasan vakum yaitu sebesar 83,15. Sedangkan nilai derajat putih terendah pada penyimpanan hari keempat dengan metode pengemasan tidak berlubang yaitu sebesar 77,02 . Perubahan derajat putih pada jamur tiram yang dikemas secara tidak berlubang dapat disebabkan oleh proses browning enzimatis jamur tiram. Menurut Arsa (2016), proses browning enzimatis disebabkan karena adanya aktivitas enzim pada bahan pangan segar, seperti pada susu segar, buahbuahan dan sayuran. Reaksi ini dapat terjadi bila jaringan tanaman terpotong, terkupas dan karena kerusakan secara mekanis yang dapat menyebabkan kerusakan integritas jaringan tanaman. Jamur tiram yang dikemas secara vakum memiliki penurunan derajat putih
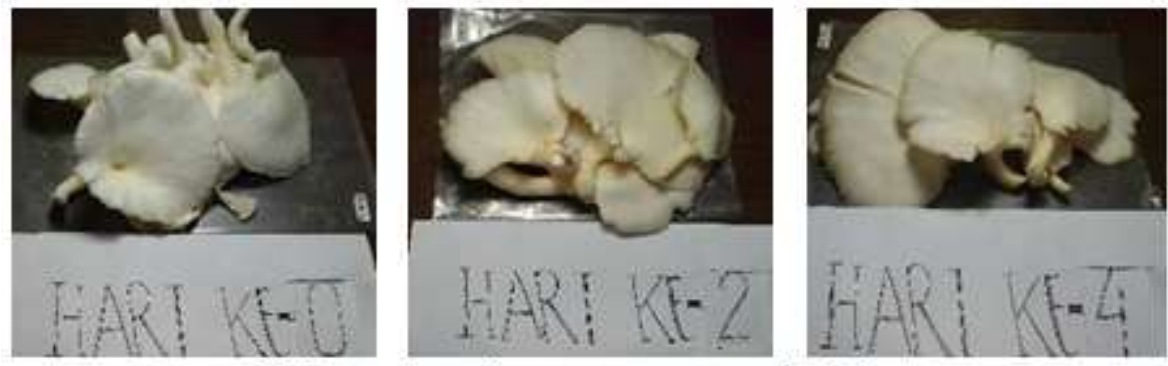

(a) Jamur tiram dengan pengemasan berlubang
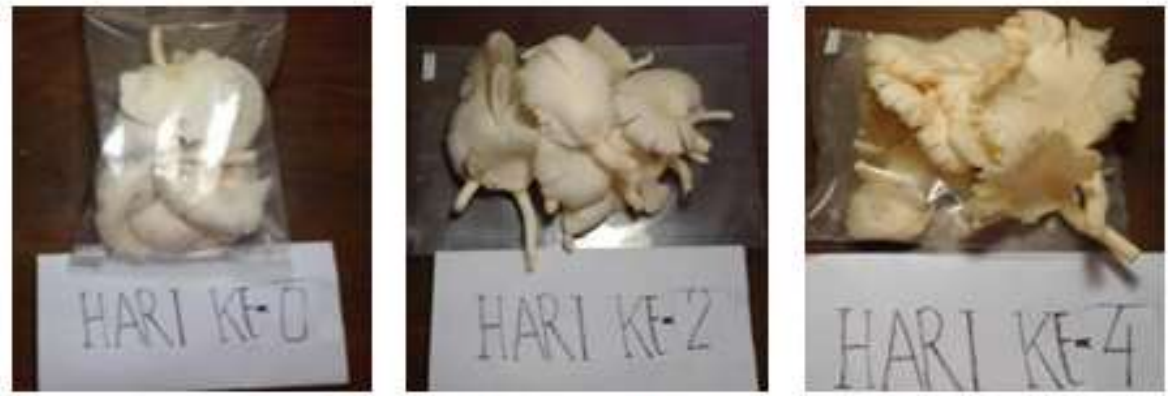

(b) Jamur tiram dengan pengemasan vakum
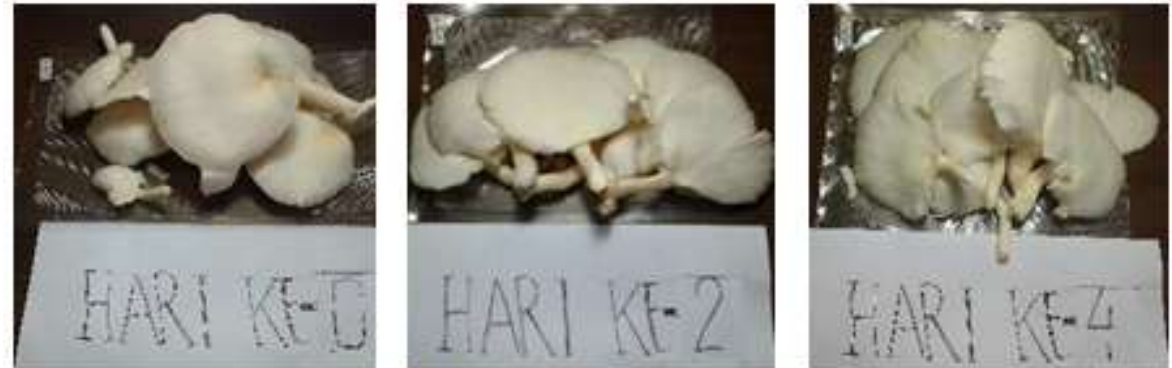

(c) Jamur tiram dengan pengemasan tidak berlubang

Gambar 2. Perubahan Warna Jamur Tiram pada Pengemasan yang Berbeda 
terendah, artinya tingkat kecerahan jamur dengan pengemasan vakum lebih baik dari tingkat kecerahan jamur dengan metode pengemasan berlubang dan tidak berlubang. Hal ini dikarenakan pada kondisi pengemasan vakum kemasannya cenderung tertutup rapat dan tidak terdapat oksigen dalam kemasan, sehingga tidak terjadi proses pertukaran udara antara kemasan dan ruang penyimpanan yang dapat mempengaruhi karakteristik mutu warna (L) pada jamur tiram. Sesuai dengan pendapat Cahya et al., (2014), pencoklatan pada jamur tiram diakibatkan adanya enzim polifenol oksidase yang apabila terkena oksigen maka akan terjadi perubahan warna. Tabel 4 menunjukkan perhitungan Anova dua arah dari metode pengemasan dan lama penyimpanan.
Hasil uji Anova diperoleh hasil berbeda nyata antara metode pengemasan dan lama penyimpanan terhadap nilai warna (L) jamur tiram. Hasil uji Tukey menunjukkan bahwa masing-masing metode pengemasan (Tabel 5) dan lama penyimpanan (Tabel 6) menunjukkan nilai berbeda nyata. Artinya terdapat pengaruh antara masing-masing metode pengemas dan lama penyimpanan terhadap nilai warna jamur tiram yang dihasilkan.

\subsection{Kadar Air Jamur Tiram}

Kadar air merupakan salah satu parameter untuk menghitung banyaknya air yang terkandung pada bahan. Pengukuran kadar air digunakan untuk menilai mutu suatu produk. Semakin banyak kadar air yang terkandung dalam bahan

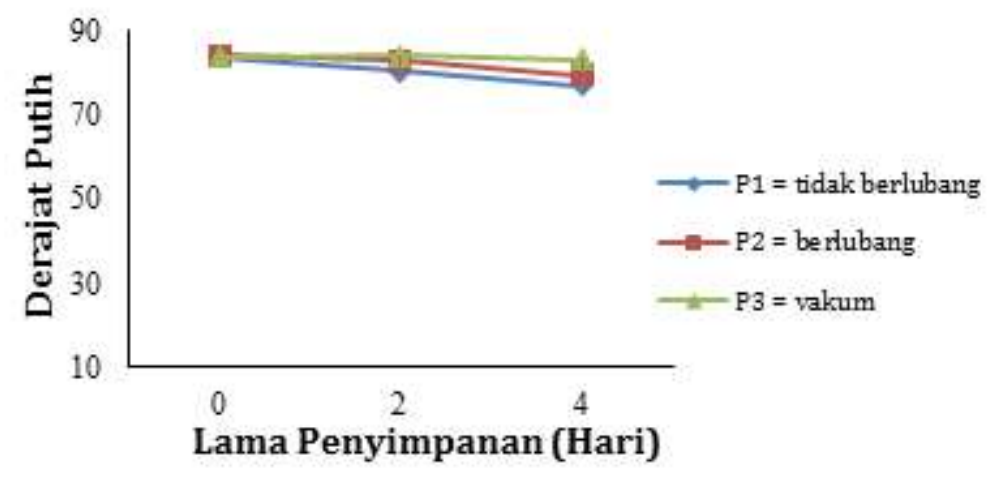

Gambar 3. Grafik Perubahan Derajat Putih Jamur Tiram

Tabel 4. Uji Anova Dua Arah Metode Pengemasan dan Lama Penyimpanan

\begin{tabular}{clccccc}
\hline $\begin{array}{c}\text { Variabel } \\
\text { Pengamatan }\end{array}$ & $\begin{array}{l}\text { Sumber } \\
\text { Variasi }\end{array}$ & $\begin{array}{c}\text { Derajat } \\
\text { Bebas }\end{array}$ & $\begin{array}{c}\text { Jumlah } \\
\text { Kuadrat }\end{array}$ & $\begin{array}{c}\text { Kuadrat } \\
\text { Tengah }\end{array}$ & $\begin{array}{c}\text { F } \\
\text { Hitung }\end{array}$ & $\begin{array}{c}\text { F } \\
\text { Tabel }\end{array}$ \\
\hline \multirow{3}{*}{ Derajat putih } & Pengemasan & 2 & 42,43 & 21,22 & $28,98^{*}$ & 3,55 \\
& Penyimpanan & 2 & 32,53 & 16,26 & $22,21^{*}$ & 3,55 \\
& Interaksi & 4 & 51,58 & 12,90 & $17,61^{*}$ & 2,93 \\
& Galat & 18 & 13,18 & 0,73 & & \\
\hline
\end{tabular}

Tabel 5. Uji Tukey Berdasarkan Metode Pengemasan

\begin{tabular}{clcc}
\hline $\begin{array}{c}\text { Variabel } \\
\text { Pengamatan }\end{array}$ & \multicolumn{1}{c}{ Komparasi } & $\begin{array}{c}\text { Beda } \\
\text { Absolut }\end{array}$ & $\begin{array}{c}\text { Nilai Kritis } \\
\text { (HSD) }\end{array}$ \\
\hline & $\begin{array}{l}\text { Tidak berlubang (P1) dengan } \\
\text { Berlubang (P2) }\end{array}$ & $1,32^{*}$ & 0,88 \\
Derajat putih & $\begin{array}{l}\text { Tidak berlubang (P1) dengan } \\
\text { vakum(P3) } \\
\text { Berlubang (P2) dengan vakum(P3) }\end{array}$ & $1,74^{*}$ & 0,88 \\
& $3,06^{*}$ & 0,88 \\
\hline
\end{tabular}

Tabel 6. Uji Tukey Berdasarkan Lama Penyimpanan

\begin{tabular}{cccc}
\hline Variabel Pengamatan & Komparasi & Beda absolut & Nilai Kritis (HSD) \\
\hline \multirow{2}{*}{ Derajad Putih } & 0 dengan 2 & 0,29 & 0,88 \\
& 0 dengan 4 & $2,46^{*}$ & 0,88 \\
& 2 dengan 4 & $2,16^{*}$ & 0,88 \\
\hline
\end{tabular}


dapat menyebabkan peluang besar terjadi kerusakan produk pangan. Grafik perubahan kadar air pada berbagai metode pengemas dan lama penyimpanan dapat dilihat pada Gambar 4.

Pada Gambar 4 dapat diketahui jamur tiram yang disimpan pada metode pengemasan vakum cenderung memiliki kadar air lebih rendah yaitu sebesar 88\% dibandingkan kadar air jamur tiram yang disimpan pada kemasan berlubang yaitu sebesar $93 \%$. Penyimpanan jamur tiram terjadi kenaikan kadar air sampai penyimpanan hari keempat. Hal ini dikarenakan terserapnya uap air hasil respirasi dalam kemasan plastik pada permukaan jamur tiram. Kadar air pada jamur tiram yang dikemas dengan berlubang cenderung memiliki kadar air yang lebih tinggi dibandingkan pengemasan tertutup. Pada pengemasan berlubang terjadi laju respirasi yang lebih tinggi dibandingkan dengan pengemasan vakum. Proses respirasi menghasilkan uap air, sehingga menyebabkan hasil pengamatan kadar air jamur tiram pada pengemasan berlubang cenderung lebih tinggi. Sesuai dengan penelitian Maulani (2003), plastik kemasan yang berlubang cenderung lebih meningkat kadar airnya, karena mampu menghasilkan air hasil proses respirasi sehingga terjadi perpindahan massa molekul karena adanya perbedaan tekanan uap di antara kedua sisi permukaan bahan jamur tiram. Hal tersebut dapat memicu tingginya kadar air pada jamur tiram. Sedangkan, pada pengemasan vakum peningkatan kadar air jamur tiram relative konstan, hal tersebut dapat terjadi dikarenakan minimnya udara yang ada pada kemasan. Berikut hasil analisis uji statistik pada metode pengemasan dan lama penyimpanan jamur tiram.

Hasil uji Anova diperoleh hasil berbeda nyata antara metode pengemasan dan lama penyimpanan terhadap nilai kadar air jamur tiram(Tabel 7). Hasil uji Tukey menunjukkan bahwa masing-masing metode pengemasan

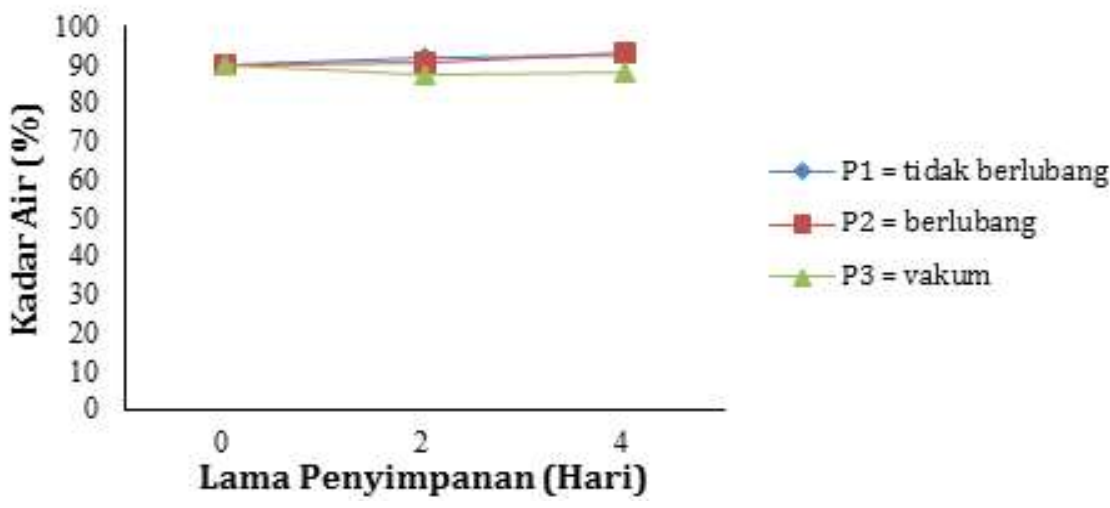

Gambar 4. Grafik Perubahan Kadar Air Jamur Tiram

Tabel 7. Uji Anova Dua Arah Metode Pengemasan dan Lama Penyimpanan

\begin{tabular}{clccccc}
\hline $\begin{array}{c}\text { Variabel } \\
\text { Pengamatan }\end{array}$ & $\begin{array}{c}\text { Sumber } \\
\text { Variasi }\end{array}$ & $\begin{array}{c}\text { Derajat } \\
\text { Bebas }\end{array}$ & $\begin{array}{c}\text { Jumlah } \\
\text { Kuadrat }\end{array}$ & $\begin{array}{c}\text { Kuadrat } \\
\text { Tengah }\end{array}$ & $\begin{array}{c}\text { F } \\
\text { Hitung }\end{array}$ & $\begin{array}{c}\text { F } \\
\text { Tabel }\end{array}$ \\
\hline \multirow{3}{*}{ Kadar Air } & Pengemasan & 2 & 73,62 & 36,81 & $7,32^{*}$ & 3,55 \\
& Penyimpanan & 2 & 2,45 & 1,22 & 0,24 & 3,55 \\
& Interaksi & 4 & 1,91 & 0,48 & 0,09 & 2,93 \\
& Galat & 18 & 90,57 & 5,03 & & \\
\hline
\end{tabular}

Tabel 8. Uji Tukey Berdasarkan Metode Penyimpanan

\begin{tabular}{clcc}
\hline $\begin{array}{c}\text { Variabel } \\
\text { Pengamatan }\end{array}$ & \multicolumn{1}{c}{ Komparasi } & $\begin{array}{c}\text { Beda } \\
\text { Absolut }\end{array}$ & $\begin{array}{c}\text { Nilai Kritis } \\
\text { (HSD) }\end{array}$ \\
\hline \multirow{3}{*}{ Kadar air } & $\begin{array}{l}\text { Tidak berlubang (P1) dengan } \\
\text { Berlubang (P2) }\end{array}$ & 0,70 & 2,31 \\
& $\begin{array}{l}\text { Tidak berlubang (P1) dengan } \\
\text { vakum(P3) } \\
\text { Berlubang (P2) dengan vakum(P3) }\end{array}$ & $3,80^{*}$ & 2,31 \\
& & $3,10^{*}$ & 2,31 \\
\hline
\end{tabular}


Tabel 9. Uji Tukey Berdasarkan Lama Penyimpanan

\begin{tabular}{cccc}
\hline Variabel Pengamatan & Komparasi & Beda absolut & Nilai Kritis (HSD) \\
\hline \multirow{2}{*}{ Kadar air } & 0 dengan 2 & 0,43 & 2,34 \\
& 0 dengan 4 & 0,73 & 2,34 \\
& 2 dengan 4 & 0,30 & 2,34 \\
\hline
\end{tabular}

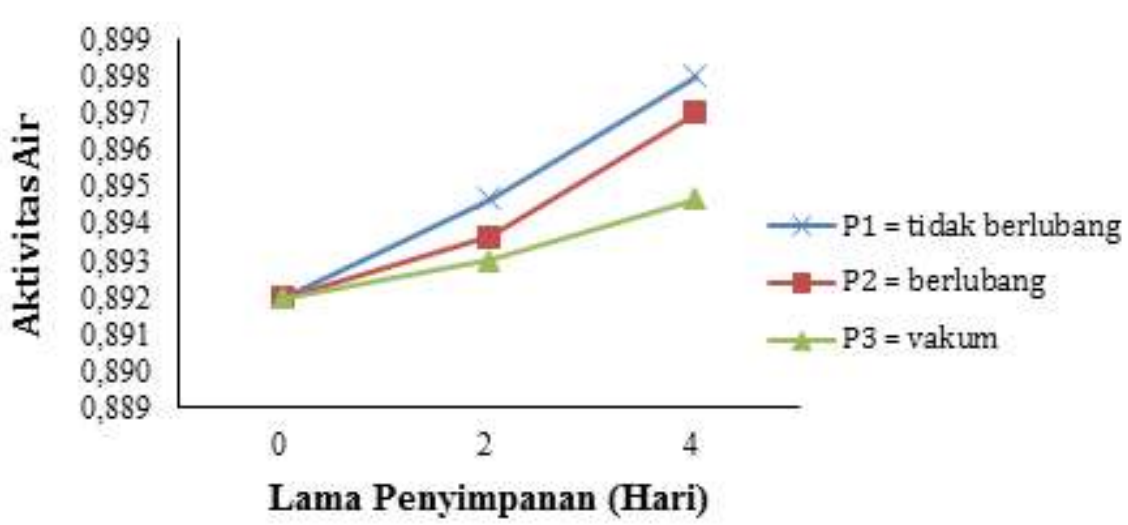

Gambar 5. Grafik Perubahan Aktivitas Air Jamur Tiram

(Tabel 8) dan lama penyimpanan (Tabel 9) menunjukkan nilai berbeda nyata. Artinya redapat pengaruh antara masing-masing metode pengemas dan lama penyimpanan terhadap nilai warna jamur tiram yang dihasilkan.

\subsection{Aktivitas Air Jamur Tiram}

Aktivitas air $\left(a_{w}\right)$ adalah jumlah air bebas yang terkandung dalam bahan pangan, yang digunakan oleh mikroba untuk pertumbuhannya (Sakti et al., 2016). Nilai diperoleh dari perbandingan tekanan uap larutan dengan tekanan uap air solven murni pada temperature yang sama. Grafik perubahan aktivitas air pada berbagai metode pengemas dan lama penyimpanan dapat dilihat pada Gambar 5.

Berdasarkan Gambar 5 dapat diketahui bahwa terjadi peningkatan nilai aktivitas air pada penyimpanan hingga hari keempat. Aktivitas air tertinggi terdapat pada jamur tiram dengan metode pengemasan berlubang dengan lama penyimpanan selama 4 hari yaitu $a_{w}$ sebesar 0,907 . Sedangkan, nilai aktivitas air terendah terdapat pada metode pengemasan vakum sebesar 0,897. Hal ini dikarenakan pada pengemasan berlubang terjadi respirasi yang lebih besar dibandingkan dengan pengemasan vakum. Proses respirasi menghasilkan uap air, sehingga menyebabkan hasil pengamatan kadar air jamur tiram pada pengemasan berlubang cenderung lebih tinggi. Tingginya nilai aktivitas air berbanding lurus dengan nilai . Sesuai dengan penelitian Cahyanti (2016), nilai kadar air, aktivitas air dan RH berbanding lurus. Kemudian lama penyimpanan juga mempengaruhi bertambahnya aktivitas air. Menurut pendapat Sari (2017), Aktivitas air sangat berpengaruh terhadap pertumbuhan mikroba, persyaratan minimal bagi mikroba dapat hidup untuk bakteri adalah 0,9 , khamir $(0,80-0,90)$ dan kapang $(0,60$ 0,70 ). Berikut tabel hasil analisis statistik pengukuran aktivitas air berdasarkan metode pengemasan dan lama penyimpanan.

Hasil uji Anova diperoleh hasil tidak terdapat beda nyata antara metode pengemasan dan lama penyimpanan terhadap nilai aktivitas air jamur tiram (Tabel 10). artinya tidak ada pengaruh antara metode pengemas dan lama penyimpanan terhadap nilai aktivitas air jamur tiram.

\subsection{Susut Bobot Jamur Tiram}

Susut bobot terjadi karena proses penyimpanan menuju pemasakan terjadi perubahan berupa pelepasan air. Menurut Lubis (2016), kehilangan air tidak saja berpengaruh langsung terhadap kehilangan kuantitatif, tetapi juga menyebabkan kerusakan tekstur, kandungan gizi dan kerusakan lain (pengerutan). Grafik perubahan susut bobot pada berbagai metode pengemas dan lama penyimpanan dapat dilihat pada Gambar 6 . 
Pada Gambar 6 diperoleh hasil bahwa jamur tiram yang disimpan mengalami peningkatan susut bobot sampai penyimpanan hari keempat. Peningkatan susut bobot berbanding lurus dengan lamanya peyimpanan. Susut bobot terbesar terjadi pada penyimpanan hari keempat pada metode pengemasan tidak berlubang. Peningkatan susut bobot terjadi karena jamur selama penyimpanan mengalami proses respirasi yang mengubah gula menjadi $\mathrm{CO}^{2}$ dan $\mathrm{H}_{2}$ Oserta terjadinya transpirasi aktif. Menurut Pudja (2009), selama penyimpanan berlangsung proses transpirasi yang menyebabkan susut bobot, akibat adanya perbedaan tekanan uap udara sekitarnya, sehingga semakin cepat proses transpirasi terjadi maka semakin cepat sayuran kehilangan bobotnya. Jamur yang dikemas secara tidak berlubang mengalami susut bobot tertinggi di hari keempat sebesar 6,65\%. Sedangkan, metode pengemasan berlubang dan vakum masingmasing memiliki rata-rata penyusutan sebesar 4,14 dan 2,47 \%. Berikut tabel hasil analisis statistik pengukuran susut bobot berdasarkan metode pengemasan dan lama penyimpanan.

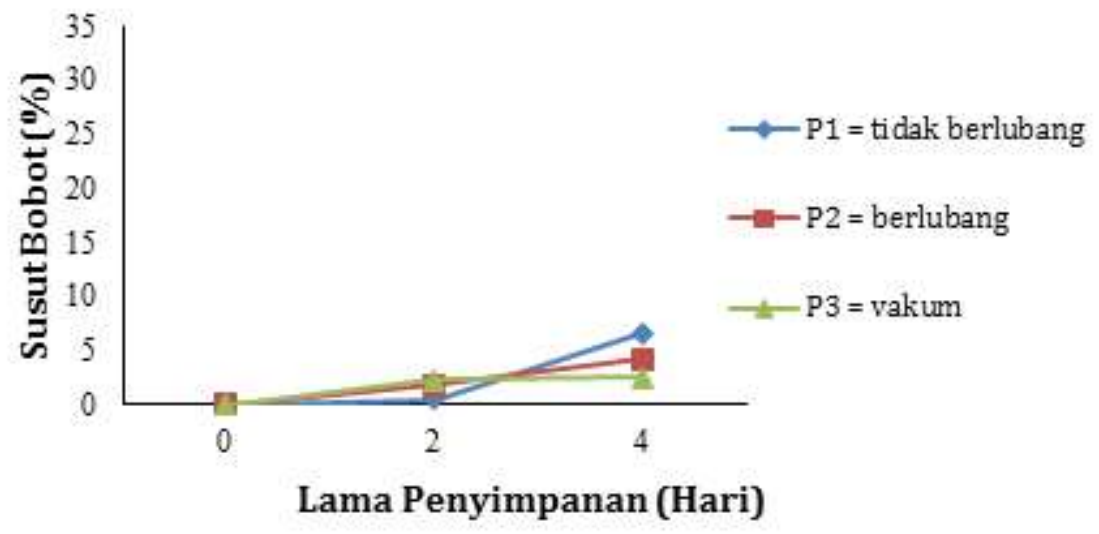

Gambar 6. Grafik Perubahan Susut Bobot Jamur Tiram

Tabel 10. Uji Anova Dua Arah Metode Pengemasan dan Lama Penyimpanan

\begin{tabular}{clccccc}
\hline $\begin{array}{c}\text { Variabel } \\
\text { Pengamatan }\end{array}$ & $\begin{array}{c}\text { Sumber } \\
\text { Variasi }\end{array}$ & $\begin{array}{c}\text { Derajat } \\
\text { Bebas }\end{array}$ & $\begin{array}{c}\text { Jumlah } \\
\text { Kuadrat }\end{array}$ & $\begin{array}{c}\text { Kuadrat } \\
\text { Tengah }\end{array}$ & $\begin{array}{c}\text { F } \\
\text { Hitung }\end{array}$ & $\begin{array}{c}\text { F } \\
\text { Tabel }\end{array}$ \\
\hline Aktivitas & Pengemasan & 2 & $4,8 \mathrm{E}-05$ & $2,4 \mathrm{E}-05$ & 0,69 & 3,55 \\
Air & Penyimpanan & 2 & $1,3 \mathrm{E}-04$ & $6,7 \mathrm{E}-05$ & 1,91 & 3,55 \\
& Interaksi & 4 & $7,9 \mathrm{E}-06$ & $2,0 \mathrm{E}-06$ & 0,06 & 2,93 \\
& Galat & 18 & $6,3 \mathrm{E}-04$ & $3,5 \mathrm{E}-05$ & & \\
\hline
\end{tabular}

Tabel 11. Uji Anova Dua Arah Metode Pengemasan dan Lama Penyimpanan

\begin{tabular}{clccccc}
\hline $\begin{array}{c}\text { Variabel } \\
\text { Pengamatan }\end{array}$ & $\begin{array}{c}\text { Sumber } \\
\text { Variasi }\end{array}$ & $\begin{array}{c}\text { Derajat } \\
\text { Bebas }\end{array}$ & $\begin{array}{c}\text { Jumlah } \\
\text { Kuadrat }\end{array}$ & $\begin{array}{c}\text { Kuadrat } \\
\text { Tengah }\end{array}$ & F Hitung & $\begin{array}{c}\text { F } \\
\text { Tabel }\end{array}$ \\
\hline \multirow{3}{*}{ Susut Bobot } & Pengemasan & 2 & 2,75 & 1,37 & $4,94^{*}$ & 3,55 \\
& Penyimpanan & 2 & 91,07 & 45,54 & $163,67^{*}$ & 3,55 \\
& Interaksi & 4 & 29,09 & 7,27 & $26,14^{*}$ & 2,93 \\
& Galat & 18 & 90,57 & 5,03 & & \\
\hline
\end{tabular}

Tabel 12. Uji Tukey Berdasarkan Metode Penyimpanan

\begin{tabular}{clcc}
\hline $\begin{array}{c}\text { Variabel } \\
\text { Pengamatan }\end{array}$ & \multicolumn{1}{c}{ Komparasi } & $\begin{array}{c}\text { Beda } \\
\text { Absolut }\end{array}$ & $\begin{array}{c}\text { Nilai Kritis } \\
\text { (HSD) }\end{array}$ \\
\hline & $\begin{array}{l}\text { Tidak berlubang (P1) } \\
\text { dengan Berlubang (P2) }\end{array}$ & 0,41 & 0,54 \\
Susut bobot & $\begin{array}{l}\text { Tidak berlubang (P1) dengan } \\
\text { vakum(P3) }\end{array}$ & $0,78^{*}$ & 0,54 \\
& $\begin{array}{l}\text { Berlubang (P2) dengan } \\
\text { vakum(P3) }\end{array}$ & 0,36 & 0,54 \\
\hline
\end{tabular}


Tabel 13. Uji Tukey Berdasarkan Lama Penyimpanan

\begin{tabular}{cccc}
\hline Variabel Pengamatan & Komparasi & Beda absolut & Nilai Kritis (HSD) \\
\hline \multirow{3}{*}{ Susut bobot } & 0 dengan 2 & $1,47^{*}$ & 0,54 \\
& 0 dengan 4 & $4,41^{*}$ & 0,54 \\
& 2 dengan 4 & $2,94^{*}$ & 0,54 \\
\hline
\end{tabular}

Hasil uji Anova diperoleh hasil berbeda nyata antara metode pengemasan dan lama penyimpanan terhadap nilai susut bobot jamur tiram (Tabel 11). Hasil uji Tukey (Tabel 12) menunjukkan bahwa masing-masing metode pengemasan tidak terdapat beda nyata, Tetapi tidak pada metode pengemasan tidak berlubang dengan vakum. sedangkan pada lama penyimpanan masing-masing perlakuan memiliki nilai yang beebeda nyata.

\section{KESIMPULAN DAN SARAN}

\subsection{Kesimpulan}

Berdasarkan metode pengemasan dan lama penyimpanan dihasilkan perlakuan terbaik jamur tiram dengan karakteristik mutu tekstur (hardness) tertinggi di hari keempat penyimpanan terdapat pada metode pengemasan vakum sebesar $0,004 \mathrm{~N} / \mathrm{mm} 2$, Nilai warna (L) tertinggi di hari keempat penyimpanan terdapat pada metode pengemasan vakum sebesar 83,15. Nilai kadar air terendah di hari keempat penyimpanan terdapat pada metode pengemasan vakum sebesar 88\%, Aktivitas air terendah di hari keempat penyimpanan terdapat pada metode pengemasan vakum sebesar 0,895 , dan nilai susut bobot terendah di hari keempat penyimpanan ada pada metode pengemasan vakum sebesar 2 , $47 \%$. Kondisi jamur dengan pengemasan vakum cenderung lembab dan tidak berair hal ini terjadi karena tekstur jamur tiram seperti spons sehingga, uap air yang terakumulasi dalam kemasan sebagai hasil respirasi terserap kembali oleh jamur. Metode pengemasan jamur tiram dan lama penyimpanan memiliki pengaruh terhadap karakteristik jamur tiram diantaranya tekstur (hardness), derajat putih, kadar air, dan susut bobot yang menunjukkan nilai karakteristik yang berbeda nyata.

\subsection{Saran}

Perlu dilakukan penelitian lanjutan mengenai pengaruh ketebalan dan jenis plastik yang digunakan. Selain itu, perlu dilakukan uji lanjutan mengenai umur simpan jamur tiram, untuk diperoleh informasi masa simpan terlama dari jamur tiram dengan metode pengemasan vakum.

\section{DAFTAR PUSTAKA}

Ann, K. C., Indarto, T., Suseno, P., dan Utomo, A. R. 2012. Gelatin Terhadap Sifat Fisikokimia Dan Organoleptik. Jurnal Teknologi Pangan Dan Gizi, 11(2): 28-36.

Arianto, D. P., Muharrani, L. K., dan Kunci, K. 2006. Karakteristik Jamur Tiram (Pleurotus ostreatus) Selama Penyimpanan dalam Kemasan Plastik Polypropilen ( PP ) Tahapan Penelitian. Agrointek, 7(2): 6675.

Arsa, M. 2016. Proses Pencoklatan (Browning Process) Pada Bahan Pangan. Diakses dari https://repositori.unud.ac.id/protected/ s torage / u pload / repositori / 39d25529666391a5efb308dbdc412214.pdf (18 Agustus 2021).

Arizka, A.A., dan Daryatmo, J. 2015. Perubahan Kelembaban dan Kadar Air Teh Selama Penyimpanan pada Suhu dan Kemasan yang Berbeda. Jurnal Aplikasi Teknologi Pangan, 4(4): 124-129.

Badan Pusat Statistik. 2019. Produksi Tanaman Sayuran 2019. Online. https:// www.bps.go.id/indicator/55/61/2/ produksi-tanaman-sayuran.html

Cahya, M., Hartanto, R., dan Novita, D. 2014. Kajian Penurunan Mutu dan Umur Simpan Jamur Tiram Putih (Pleurotus ostreatus) Segar Dalam Kemasan Plastik Polypropylene Pada Suhu Ruang dan Suhu Rendah. Jurnal Teknik Pertanian Lampung, 3(1): 35-48. 
Cahyanti, M. N. C. 2016. Pemodelan Isoterm Sorpsi Air Biskuit Coklat Menggunakan Persamaan Caurie. Jurnal Aplikasi Teknologi Pangan, 5(2): 51-53.

Lubis, A. 2016. Aplikasi Metode Respon Surface untuk Optimasi Kuantitas Susut Bobot Buah Manggis. Fakultas Pertanian, April 2012, 12.

Marbun, F. G. I., Wiradimadja, R., dan Hernaman, I. 2019. Pengaruh Lama Penyimpanan Terhadap Sifat Fisik Dedak Padi. Jurnal Ilmiah Peternakan Terpadu, 6(3): 163.

Maula, M., Bekatul, D., Sains, D., dan Industri, K. 2018. Air Kelapa Terhadap Pertumbuhan dan Hasil Jamur Tiram Putih (Pleurotus ostreatus). Agroswagati, 6(1): 646-656.

Maulani, R. R. 2003. Perubahan Ffisiologis Jamur Tiram (Pleurotus ostreatus) Segar Selama Penyimpanan Dalam Kemasan Polietilen Dan Polipropilen Berperforasi. Institut Pertanian Bogor.
Pudja, I.A.R.P. 2009. Laju Respirasi dan Susut Bobot Buah Salak Bali Segar pada Pengemasan Plastik Polyethylene Selama Penyimpanan dalam Atmosfer Termodifikasi. Agrotekno, 15(1): 8-11.

Sakti, H., Lestari, S., dan Supriadi, A. 2016. Perubahan Mutu Ikan Gabus (Channa Striata) Asap Selama Penyimpanan. Jurnal Teknologi Hasil Perikanan, 5(1): 11-1818.

Sari, S. R. 2017. Profil Mutu Ikan Lele (Clarias Gariepinus) Asap yang Diberi Perlakuan Gambir (Uncaria gambir Roxb.). Jurnal Dinamika Penelitian Industri, 28(2): 101111.

Zulfika, D. N. 2018. Menggunakan Metode Pengemasan Vakum. Seminar Nasional Penelitian Dan Pengabdian Masyarakat, 63-66. 